\title{
AC 2010-2114: INTEGRATING CULTURAL DEVELOPMENT INTO A MULTI-DISCIPLINARY SEMINAR COURSE: BROADENING THE STUDENT HORIZON TO BETTER FUNCTION AND APPRECIATE GLOBAL, CONTEMPORARY ISSUES
}

\section{David Cottrell, University of North Carolina, Charlotte}

DR. DAVID S. COTTRELL is an Assistant Professor in the Department of Engineering Technology, University of North Carolina at Charlotte. He graduated from the United States Military Academy in 1978 and retired in 2000 after more than 22 years of service with the US Army Corps of Engineers. Studies at Texas A\&M University resulted in an MS Degree in Civil Engineering in 1987 and a PhD in 1995. He is a registered Professional Engineer with the Commonwealth of Virginia. With more than 13 years professorial experience, he has taught a large variety of courses including statics, dynamics, mechanics of materials, graphic communications, engineering economy, and construction planning, scheduling, estimating, and management. 


\section{Integrating Cultural Development into a Multi-Disciplinary Seminar Course: Broadening the Student Horizon to Better Function and Appreciate Global, Contemporary Issues}

\section{Introduction}

This paper describes practical techniques currently employed to effectively integrate ABET accreditation criteria for engineering technology ${ }^{1}$ into a junior-level seminar course. With enrollment open to electrical, mechanical, and civil engineering technology as well as construction management students, this course provides a unique, multi-disciplined atmosphere to address the many aspects of engineering "soft" skills both as a student and as a future practicing engineer. In particular, this paper will discuss innovative, strategic teaching initiatives for assessment and evaluation of specific Program Outcomes noted under TC2K Criterion 3 and recognized throughout the engineering community as essential skills that allow engineers to effectively function and grow as members of the society that they serve. These outcomes are noted below lettered appropriately as they appear in the ABET criterion:

e. An ability to function effectively on teams.

g. An ability to communicate effectively.

h. A recognition of the need for, and an ability to engage in lifelong learning

i. An ability to understand professional, ethical and social responsibilities.

j. A respect for diversity and knowledge of contemporary professional, societal and global issues.

k. A commitment to quality, timeliness, and continuous improvement.

Although generally considered a "non-technical" course, this paper describes the use of a junior professional seminar to provide a unique perspective on integrating engineering disciplines in the classroom as a model of their future "team-oriented" relationships in the real world. This course is structured to be a multi-disciplined environment where third-year engineering technology students can explore a number of relevant topics pertinent to their success as a student as well as a future practicing engineer. The resulting diversity served well as a precursor to examining these outcomes from different engineering perspectives. The teaching strategy necessarily recognizes that an ability to understand professional, ethical, and social responsibilities extends quite naturally into the other areas of emphasis included in the outcomes. Presentations and class work include traditional instruction, guess speakers, group projects, extensive writing, and student presentations on selected topics. This paper will present several innovative techniques for addressing, assessing, and evaluating the outcomes noted above and provide insights into the benefits of integrating electrical, mechanical, and civil disciplines into the same learning environment. Additionally, this paper will present a unique approach to incorporating out-ofthe-classroom social and community events that provide timely opportunities for students to 
broaden their cultural horizons and to reconsider numerous contemporary, global issues. In each of the six criteria discussed in this paper, student feedback and assessment data is presented. The primary medium for collecting student feedback was via end-of-semester surveys.

\section{a. An Ability to Function Effectively on Teams (ABET Criteria e)}

A time tested principle in education stipulates that a student best learns by doing; developing team skills is certainly no exception. During this course, students work in teams of 3-4 to research and prepare two short in-class presentations. Student teams research the industry in their own respectively chosen fields - electrical, mechanical, civil engineering technology, and construction management. Relevant industry representatives may result from personal experience or from exterior research and must be equal in number to the quantity of members on the team - i.e., three members $=$ three companies; four members $=$ four companies.

The first student presentation examined documented, expressed commitments by industry representatives to promote diversity both internally within the company and externally through initiatives implemented to accommodate a diverse clientele/customer base. Presentations included for each of the selected industry representatives:

- Company background and industry capacity;

- Ongoing initiatives which testify to their commitments to diversity in the employees (hiring, promotion, sensitivity/awareness training, etc.);

- Marketing strategy which actively tailors to serving a diverse clientele/customer base.

The second student presentation retained a focus on surveying industry representatives but concentrated on two additional areas on interest:

- Ongoing initiatives testifying to a commitments to quality control and continuous improvement in their products/service as well as customer base;

- Expectations for employees to continue their respective education.

The continuous education research encompassed a number of potential areas including formal programs interior to the company for training through workshops or seminars, company support in terms of time and money to attend workshops, conventions, and academic courses, reimbursement of tuition for college level training or preparatory classes, etc.

Certification/recertification for professional credentials was also considered. For instance, if the company promotes Professional Engineer Registration, students researched if they also support review classes for taking the exam as well as opportunities for the employee to obtain Continuing Education Units (CEUs) to maintain the license. Finally, students completed an overall formal comparative assessment of the companies in terms of the areas covered in the briefing. For each of the respective categories, student teams determined a minimum of three criteria to assess the relative strengths of the companies, assign an appropriate weight for the criterion, and compute an appropriate score for each company. This collective comparison proved particularly key to the development of effective team skills. It should be noted that both 
presentations focused on real companies and aided not only in researching industry's commitment to diversity, quality, and continuous education but also to raise the awareness of the class to potential future employers.

The final grade for the projects employed a deliberate rubric which assessed both the content as well as their ability to function effectively on a team. Both student presentations were focused with distinct expectations for content; nevertheless, a key part of the evaluation dealt with oral communication skills and the manner in which they presented the results of their research. To assess group and team effectiveness, the final grade incorporated peer evaluations designed to measure their ability to contribute to the overall group effort to prepare and conduct the presentation.

To assess their ability to function well on teams, assessment efforts documented the percentage of students who participated effectively on teams based on peer evaluations. The peer evaluations mechanism systematically awarded scores greater than or equal to 1.0 to those students who performed in an acceptable or exceptional manner (See Appendix A for more details on the Peer Evaluation process). Consequently, the assessment measure was defined as the percentage of students who demonstrated their ability to function on a team by scoring at least 1.00 on peer evaluations. The results for this iteration as well as previous semesters are presented below:

Table 1: Assessment results for effectively functioning on a team

\begin{tabular}{|c|c|c|c|c|c|c|}
\hline \multirow{2}{*}{ Target } & \multicolumn{7}{|c|}{ Assessment Results } \\
\cline { 2 - 7 } & $\begin{array}{c}2005 \\
(\text { Fall })\end{array}$ & $\begin{array}{c}2006 \\
(\text { Fall })\end{array}$ & $\begin{array}{c}2007 \\
(\text { Fall })\end{array}$ & $\begin{array}{c}2008 \\
(\text { Fall })\end{array}$ & $\begin{array}{c}2009 \\
(\text { Spring })\end{array}$ & $\begin{array}{c}2009 \\
(\text { Fall })\end{array}$ \\
\hline $80 \%$ & $77 \%$ & $84 \%$ & $73 \%$ & $100 \%$ & $100 \%$ & $74.1 \%$ \\
\hline
\end{tabular}

Assessment of the data clearly indicates the variability of this measure. Previous discussions among the faculty recommended sustainment of peer evaluations as an effective protocol for assessing student participation and group work. However, it was recommended that the curriculum be modified to provide instruction directly on group dynamics and the need to recognize certain roles in a well-functioning group. It is unfortunate that although this class on group dynamics was implemented this semester, the $74.1 \%$ reports a significant drop in performance and fails to meet the targets value. Faculty consensus concluded an explanation must lie elsewhere. The alignment on the number of students to the number of companies actually undermined group unity. Students worked separately on their "company" and little true group effort was necessary except for final integration of slides/information just previous to the presentation. Next iteration, the format must be modified in order to compel a collective group effort for success. 
The traditional end-of-semester surveys provided another opportunity to gather feedback on a number of areas of concern. While this assessment technique is subjective, it nevertheless provided the faculty with a measure of the student's perception regarding these critical area of their education. For functioning effectively on teams, students responded to the following questions:

a1. "Based on the classroom instruction and discussions, this class enhanced my ability to function on teams."

a2. "The peer evaluations served well to assess how well my team functioned."

a3. "The group projects aided in improving my ability to function on a team."

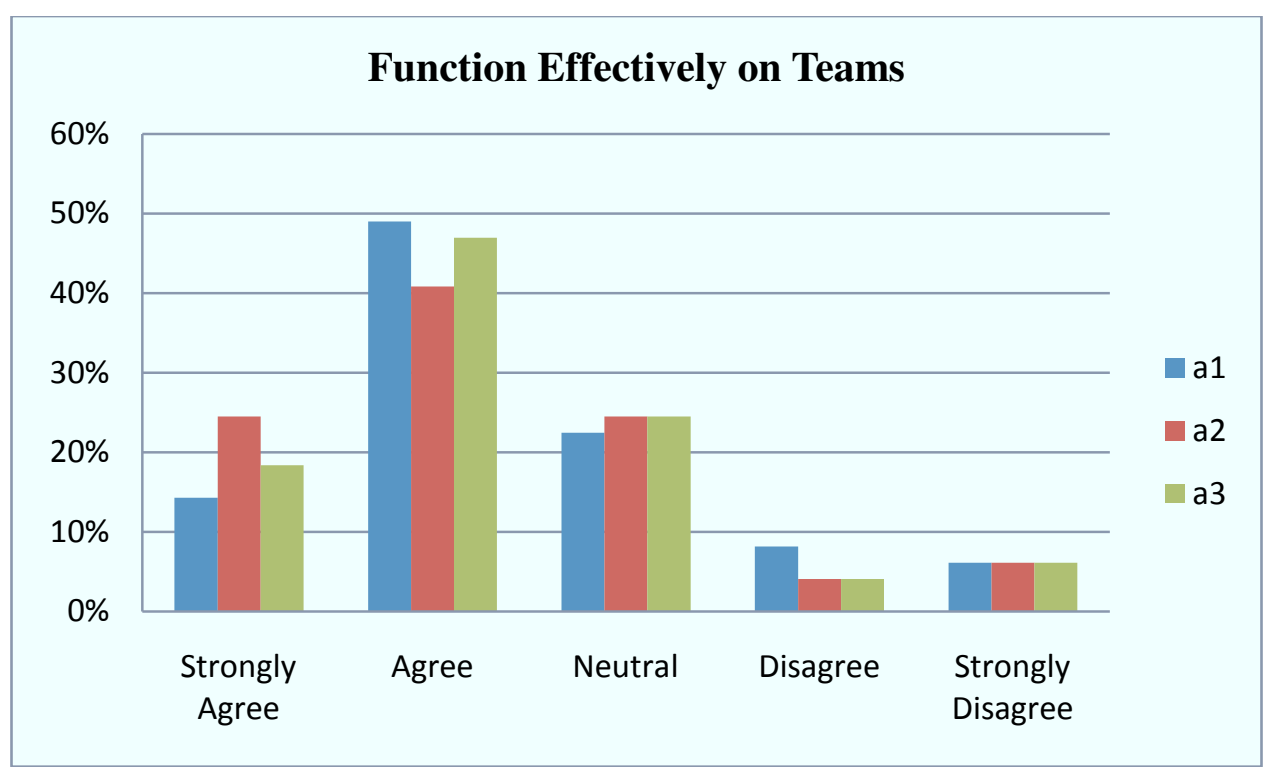

Figure 1: Student response to questions a1, a2, and a3 noted above.

(Note: $\mathrm{N}=49$ student responses.)

Figure 1 displays a favorable student response for the first criteria. For each of the three areas, over $63 \%$ of the students agreed or strongly agreed with the statements $(\mathrm{a} 1=63 \%, \mathrm{a} 2=65 \%$, a3 $=65 \%$ ). Nevertheless, written student comments also indicate that there remains room for improvement. Classroom discussion and lectures on team dynamics seemed to be too passive; developing team skills must include active demonstrations and practical exercises whenever possible. The two group project methodology served extremely well as a medium for developing and demonstrating individual team skills. The topics were apparently viewed as timely and relevant, and the students eagerly pursued the research of "future potential employers" with relish. The peer evaluations worked well to evaluate team member effectiveness but did not coach students on improvement strategies. Although overall peer evaluations improved from the $1^{\text {st }}$ presentation to the $2^{\text {nd }}$, more deliberate feedback would be beneficial. 


\section{b. An Ability to Communicate Effectively (ABET Criteria g)}

Certainly, the group presentations further proved to be a crucial element in assessing oral communications abilities. To assess this area, the program documented the percentage of students who achieved a score of $90 \%$ or better for their oral presentation on diversity in industry. The target for the collective performance of the class was $80 \%$.

Table 2: Assessment results for effective oral communication.

\begin{tabular}{|c|c|c|c|c|c|c|}
\hline \multirow{3}{*}{ Target } & \multicolumn{7}{|c|}{ Assessment Results } \\
\cline { 2 - 7 } & $\begin{array}{c}2005 \\
(\text { Fall })\end{array}$ & $\begin{array}{c}2006 \\
(\text { Fall })\end{array}$ & $\begin{array}{c}2007 \\
(\text { Fall })\end{array}$ & $\begin{array}{c}2008 \\
(\text { Fall })\end{array}$ & $\begin{array}{c}2009 \\
(\text { Spring })\end{array}$ & $\begin{array}{c}2009 \\
(\text { Fall })\end{array}$ \\
\hline $80 \%$ & $99 \%$ & $93 \%$ & $85 \%$ & $87 \%$ & $81 \%$ & $92 \%$ \\
\hline
\end{tabular}

Previous recommendations for this area were twofold: (1) Narrow the scope for the oral presentations to a single topic of interest. This project originally included instructions for the students to research both quality control and diversity; this semester, the assignment was narrowed to only address diversity in order to better focus the students on the importance of this topic. (2) Presentation Skills: A class lecture needs to be added to the course curriculum to better instruct the students on the fundamentals of developing and presenting a formal oral presentation supported by PowerPoint slides. These recommendations were implemented, but the format associated with the assignment (as discussed earlier - see previous section/discussion) undermined the ability of the groups to present well or to function as a team. Limited group interaction generally limited any bonding and certainly rehearsal was individual if it happened at all. Nest semester, the presentation must be modified to compel group work.

To address the writing component of communication, this course builds on the tenet that a student becomes a good writer first and foremost by writing - numerous times. Consequently, the students wrote and submitted four (4) papers during the semester on a variety of assigned topics including:

- “Time Management: Organizing for Academic Success." Students were required to implement the time-management techniques discussed during class and developed during the in-class practical exercise where you produced a schedule depicting class attendance, study time, meals, work, social activities, and physical exercise. The writing assignment addressed the degree of effectiveness the student encountered while attempting to follow their schedule template.

- "Self-Advertising Monologue." Students were challenged to capture the essence of their experience, talent, skills, aptitude, objectives, and other appropriate attributes that specifically aligned them with a future employer and his organization. This paper was designed to depict what the student would tell a perspective employee 
when they ask, "Nice to meet you. Tell me a little about yourself." In short, the students had to develop a concise statement making a case on why they should be hired.

- "Living Professionally and Ethically." This paper focused on engineering ethics and diversity in the industry consistent with the students' chosen field. They could address a particular code or canon of ethics put forth by a professional society (ASCE, ASME, IEE, etc.) or a set of ethics standards published by a particular company. The paper should examine how ethics and diversity are linked; for instance, explore what is meant by some that "ethics should be color blind in application." Additionally, the paper should ultimately describe the students' personal commitment to living professionally and ethically.

- "Life-long learning - School Never Stops." Students discussed their commitment to pursuing education after graduation including formal training at their firm, on-the-job training opportunities consistent with mastering the fundamentals of their job, and/or formal educational opportunities (seminars, workshops, college courses, graduate degree, etc.).

The student papers were graded based on content as well as proper grammar and composition standards. However, to foster continuous improvement in this critical area, all written works could be resubmitted after rewrites to improve performance. Administratively, students wishing to take advantage of this opportunity must submit the work within one week. Students were strongly encouraged to coordinate directly with the English graders to gain insight on how they might improve.

For this area of communication, students' end-of-semester feedback responded to the following questions:

b1. "The written submissions aided in developing my ability to write effectively."

b2. "Resubmitting graded submissions improved my writing ability by providing the opportunity to implement recommendations for improvement."

b3. "The group presentations were beneficial in developing my ability to prepare and present a formal briefing."

Figure 2 displays the student feedback for each of the three areas. The first two statements collectively endorse the effectiveness of the writing program with over $61 \%$ of the students responding that they agreed or strongly agreed $(b 1=69 \%, b 2=61 \%)$. Extending the assessment to include students who were neutral, the numbers jump to $84 \%$ and $94 \%$. The final statement reinforces the earlier discussion dealing with the oral presentations (See Section "a" above). Over $82 \%$ of the students agreed or strongly agreed that the group presentations were effective in not only developing their skills in preparing and presenting orally but also in bolstering their confidence in tackling what can sometimes be a very challenging, nerve-racking mission speaking in public. 


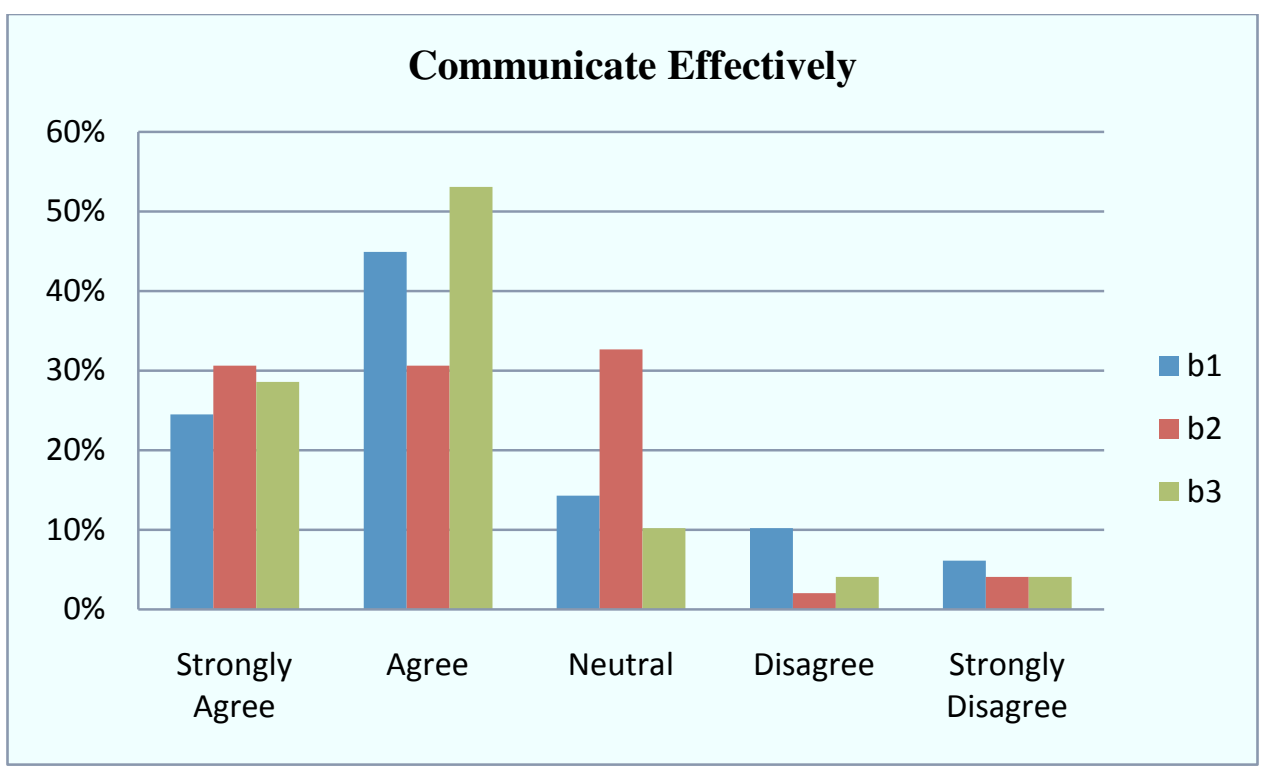

Figure 2: Student response to questions b1, b2, and b3 noted above.

(Note: $\mathrm{N}=49$ student responses.)

\section{c. A Recognition of the Need for and an Ability to Engage in Life-Long Learning (ABET Criteria h)}

Raising student awareness of this particular expectation is certainly challenging insofar as it addresses a trait that should not truly manifest itself until after graduation. Nevertheless, the strategy in this course was very deliberate and included three specific initiatives. First, classroom instruction demonstrated for the student the rapid evolution of technology over the past 35 years with examples of scientific technology of the times - calculators (a slide rule, an early calculator from the '80's, an HP 48 graphing calculator), data storage devices (5 1/4 inch floppy disk, $31 \frac{1}{2}$ inch disk, zip drives, and memory sticks), and telephones (early dial phones, touch-tone technology, portable/car phones from the '90's, the iPhone). Discussion easily evolved into predictions of possibilities for the future and how technology might further evolve and affect their practice as engineers. The need to continue learning to keep abreast of the rapid growth of technological evolution became a foregone conclusion, but one that the students seemed to embrace rather than accept grudgingly. The other two initiatives have already been discussed above but not specifically in this context. The fourth writing requirement (See Section " $b$ " above) followed the classroom discussion on life-long learning and provided a forum for the student to testify as to their personal recognition of the need and to articulate their plans to pursue this necessary component of their professional lives. The second student presentation (See Section "a" above) reinforced their intuitive realization of the need with research within the industry that formally expressed life-long learning as an imperative for job security.

Assessment in this area measured the percentage of students who attended the lecture on lifelong learning and subsequently received at least $80 \%$ on the follow-up writing requirement: an essay addressing the validity of the need for lifelong learning, the expectations of potential employers for employee continued learning and education, and the student's plan for personally 
Table 3: Assessment results for recognition of the need for and an ability to engage in life-long learning.

\begin{tabular}{|c|c|c|c|c|c|c|}
\hline \multirow{3}{*}{ Target } & \multicolumn{6}{|c|}{ Assessment Results } \\
\cline { 2 - 7 } & $\begin{array}{c}2005 \\
\text { (Fall) }\end{array}$ & $\begin{array}{c}2006 \\
(\text { Fall) }\end{array}$ & $\begin{array}{c}2007 \\
(\text { Fall })\end{array}$ & $\begin{array}{c}2008 \\
(\text { Fall })\end{array}$ & $\begin{array}{c}2009 \\
(\text { Spring })\end{array}$ & $\begin{array}{c}2009 \\
(\text { Fall })\end{array}$ \\
\hline $80 \%$ & $97 \%$ & $99 \%$ & $89 \%$ & $94 \%$ & $63 \%$ & $90.9 \%$ \\
\hline
\end{tabular}

engaging in a program of lifelong learning. (See previous section for discussion of writing assignments.) Table 3 presents the historic performance in this area.

Previous recommendations for this area of assessment focused on sustaining the current policies and programs already in place in spite of the percentage drop noted during Spring Semester 2009. Spring 2009 was considered an anomaly with a single section and enrollment less than 25 students rather than the normal expectation in the Fall of five - six sections with enrollment closer to 125. However, there are some slight scheduling changes in the timing for this particular requirement. The research project dealing with the industry's education programs will be coupled with research in diversity in industry. This aspect will more closely align classroom discussions within the curriculum schedule with presentation of group projects.

Student feedback on life-long learning issues responded to the following questions:

c1. "The classroom discussions and the written submittal on the need for lifelong education helped my recognition of the need for pursuing education after graduation."

c2. "The second group presentations allowed me to see the expectation within the industry for lifelong learning."

c3. "I have personally made plans to pursue professional registration or a graduate degree sometime after graduation."

Figure 3 on the next page displays the student feedback for each of the three areas. Students seem to indicate that the course is particularly effective in raising their awareness of this issue. The first two statements collectively address the initiatives within this course with over $73 \%$ of the students responding that they agreed or strongly agreed with the proposed statements $(\mathrm{c} 1=$ $73 \%, \mathrm{c} 2=78 \%$ ). The third statement attempts to solicit testimony about future plans and gives a collective student response of 53\% who at least agree with the need to plan for future education. This lukewarm response perhaps is not surprising considering these students were $1^{\text {st }}$ semester juniors; students at this point in their academic programs do not normally possess well-defined, post-graduate education plans. Nevertheless, extending the assessment to include students who were neutral, the numbers jump to $92 \%$ which the researcher considers as a favorable indication that at least they recognize the need for continued learning. 


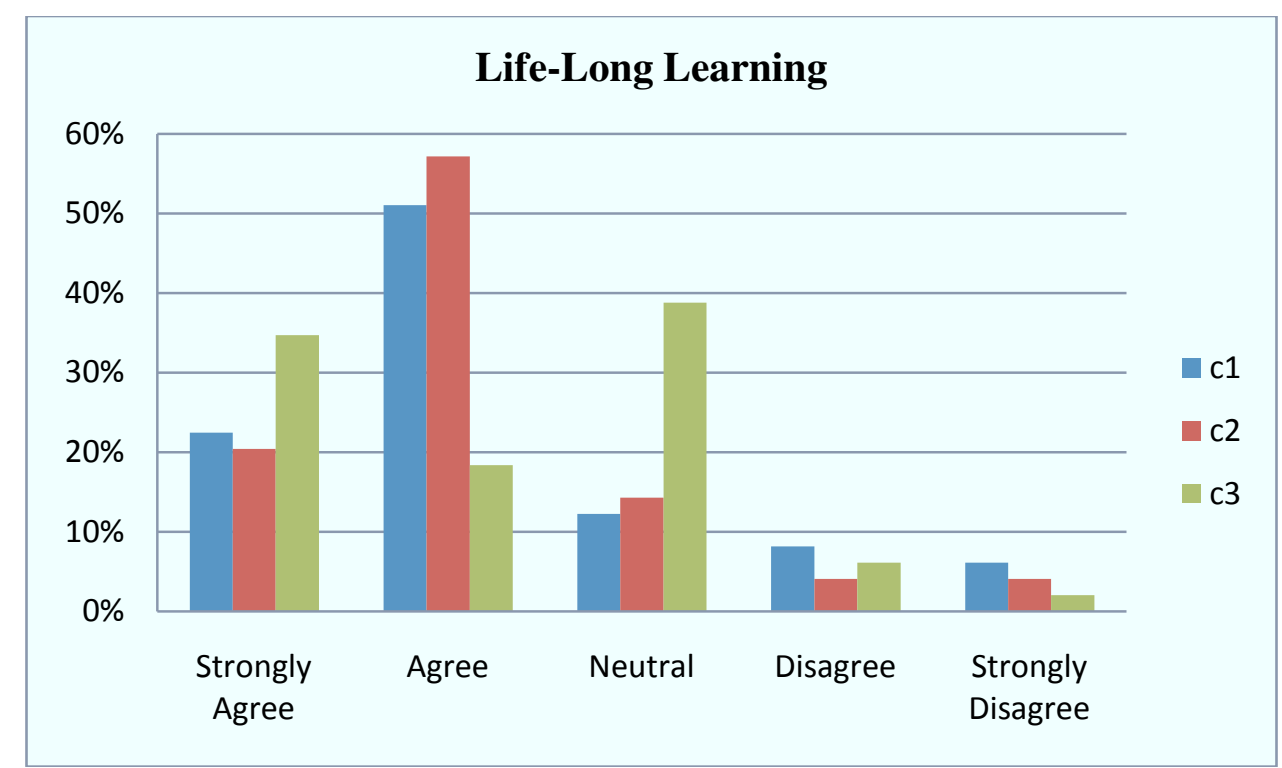

Figure 3: Student response to questions c1, c2, and c3 noted above.

(Note: $\mathrm{N}=49$ student responses.)

\section{d. An Ability to Understand Professional, Ethical, and Social Responsibilities (ABET Criteria i)}

Some of the initiatives discussed earlier that proved effective for other outcomes also served for assessing the ability to understand professional, ethical, and social responsibilities. Certainly the writing assignments (See Section "b" above) provided an excellent venue to not only develop their writing skills but also to explore other topics of interest relevant to their future as practicing engineers. The $3^{\text {rd }}$ writing assignment, "Living Professionally and Ethically," focused on ethics and diversity in the industry and ultimately described the students' personal commitment to professional ethics. Similarly, the first student presentation on diversity discussed earlier (See Section "a" above) also represented a timely opportunity for the students to understand the societal and industry expectations for professional and ethical behavior from the engineering profession that is ultimately charged to serve the public interest.

Table 4: Assessment results regarding the student's ability to understand professional, ethical, and social responsibilities.

\begin{tabular}{|c|c|c|c|c|c|c|}
\hline \multirow{2}{*}{ Target } & \multicolumn{7}{|c|}{ Assessment Results } \\
\cline { 2 - 7 } & $\begin{array}{c}2005 \\
(\text { Fall })\end{array}$ & $\begin{array}{c}2006 \\
(\text { Fall })\end{array}$ & $\begin{array}{c}2007 \\
(\text { Fall })\end{array}$ & $\begin{array}{c}2008 \\
(\text { Fall })\end{array}$ & $\begin{array}{c}2009 \\
(\text { Spring })\end{array}$ & $\begin{array}{c}2009 \\
(\text { Fall) }\end{array}$ \\
\hline $80 \%$ & $100 \%$ & $100 \%$ & $93 \%$ & $97 \%$ & $81 \%$ & $90.9 \%$ \\
\hline
\end{tabular}


Table 4 presents the historical assessment data for this area. The measure is defined as the percentage of students who attended a lecture on professional ethics and subsequently received at least $80 \%$ on the writing requirement addressing the validity of ethics as practical guidelines to understand professional, ethical and social responsibilities. The targeted level of performance for the course was $80 \%$. Recommendations focus on sustaining the current policies and programs already in place in spite of the percentage drop noted during spring 2009.

Student feedback addressed the collective methodology that encompassed discussion, essays, and presentations. Students responded to the following questions:

d1. "Classroom discussions regarding professional, ethical, and social responsibilities helped in developing a better understanding of my responsibilities as a practicing engineer."

d2. "The paper I wrote on professional ethics within the industry aided in my understanding of my responsibilities as a practicing engineer."

d3. "The first [student] presentation on diversity issues in my industry helped in developing in me a better understanding of my professional, ethical, and social responsibilities as a practicing engineer."

Figure 4 provides a favorable response to all three questions. $81 \%$ agreed that the classroom lecture and discussions on this topic were beneficial and $69 \%$ and $71 \%$ respectively agreed that the writing requirement and the research project were timely reinforcements. The methodology here is not subtle, and the students seem to understand the importance of their professional, ethical, and social responsibilities as a practicing engineer.

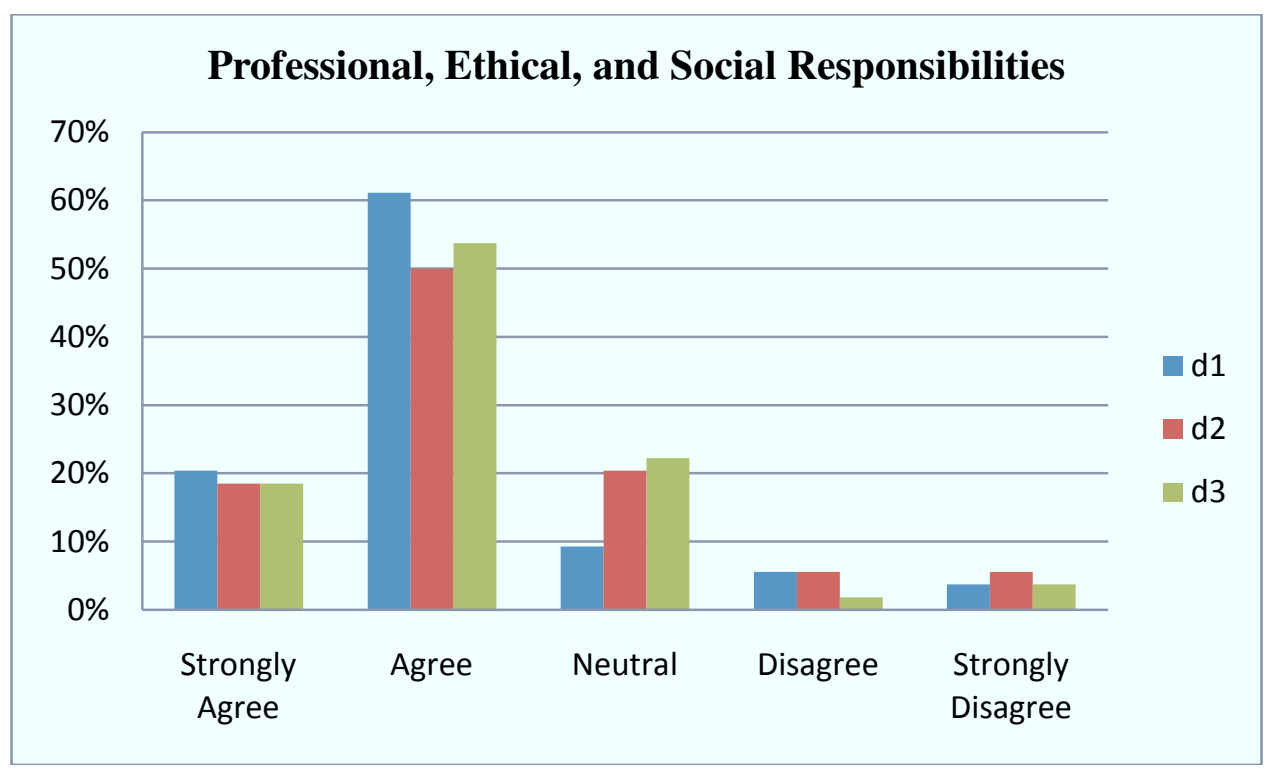

Figure 4: Student response to questions d1, d2, and d3 noted above.

(Note: $\mathrm{N}=54$ student responses.) 


\section{e. A Respect for Diversity and Knowledge of Contemporary Professional, Societal, and Global Issues (ABET Criteria j)}

Although certainly addressed during the classroom discussions, the central piece of cultural diversity education sprang from a requirement for students to select and attend outside-theclassroom cultural events. Students were required to select and attend a minimum of four (4) events that would ultimately broaden their cultural horizon. The course syllabus published a number of events that are provided through the University Multi-Cultural Resource Center (See Appendix B for a list from this semester). These events change each semester and typically offer a diverse array of subjects and guest speakers. Students may select from this pre-approved list or select a cultural event of their own device that may include tours of government buildings, museums, cultural festivals, or even some movies. However, events not listed as "pre-approved" in the course syllabus below had to be cleared with the instructor to ensure they rose to the level of cultural significance warranted by this course. Assessment forms were provided for the students to describe the event and its impact on the students' grasp of diversity and/or their knowledge of contemporary professional, societal and global issues.

Students in this course were expected to maintain a grasp and have contemporary knowledge of professional, societal and global issues. To encourage the development of a thirst for keeping track of the world around them, unannounced mini-quizzes were administered during the semester covering significant current news and events. Subject areas that were tested were diverse covering national and international politics, economics, sports, and entertainment.

Assessment efforts documented the percentage of students who attended at least two of the outside-the-class cultural events. Table 5 presents historical performance in this area with a targeted criteria of $80 \%$.

Table 5: Assessment results for cultural diversity education initiatives.

\begin{tabular}{|c|c|c|c|c|c|c|}
\hline \multirow{2}{*}{ Target } & \multicolumn{7}{|c|}{ Assessment Results } \\
\cline { 2 - 7 } & $\begin{array}{c}2005 \\
(\text { Fall })\end{array}$ & $\begin{array}{c}2006 \\
(\text { Fall })\end{array}$ & $\begin{array}{c}2007 \\
(\text { Fall })\end{array}$ & $\begin{array}{c}2008 \\
(\text { Fall })\end{array}$ & $\begin{array}{c}2009 \\
(\text { Spring })\end{array}$ & $\begin{array}{c}2009 \\
(\text { Fall) }\end{array}$ \\
\hline $80 \%$ & $100 \%$ & $97 \%$ & $93 \%$ & $100 \%$ & $81 \%$ & $97.9 \%$ \\
\hline
\end{tabular}

Recommendations for this topic of assessment focus on sustainment of an apparently effective tool regarding developing a respect for diversity and knowledge of contemporary professional, societal and global issues.

Student end-of-semester feedback naturally solicited input on the effectiveness of the cultural events, the current events quizzes, and associated classroom discussions. Specifically, students responded to the following questions: 
e1. "The cultural events I attended this semester were effective in helping me develop a deeper respect for diversity and broaden my cultural horizon."

e2. "The current events quizzes encouraged me to develop a better appreciation for international and national societal issues in such diverse fields as politics, sports, and entertainment."

e3. "Classroom discussions regarding industry codes of ethics clearly communicated the expectations of responsible, ethical behavior for practicing engineers."

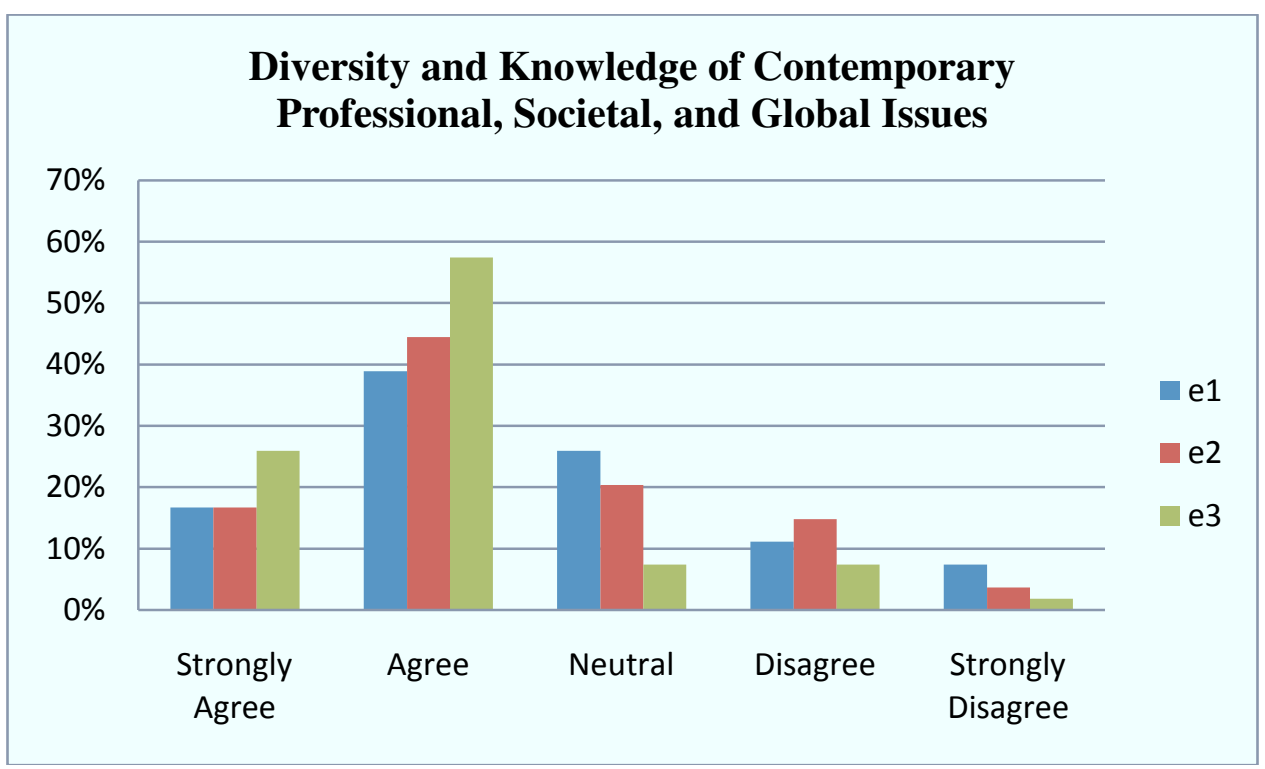

Figure 5: Student response to questions e1, e2, and e3 noted above.

(Note: $\mathrm{N}=54$ student responses.)

For at least the first two questions, Figure 5 reveals a generally positive response but certainly not as strong as some of the areas previously discussed. For the cultural event program, only $56 \%$ at least agreed that the events were effective. Unfortunately, this may be a deficiency in the program itself or perhaps more to the point, a reflection on the individual events chosen by the students. Students select an event in the hopes that it will prove to be beneficial. However, if the event fails to live up to expectations, there is no requirement for the student to select a second event to replace the non-effective one. Consequently, the student responses here may to some extent be a reflection of the collective quality of the events rather than a verdict on the program itself. The students scored the current events quizzes as generally effective with over $61 \%$ responding that they agreed or strongly agreed. This is particularly interesting as the connection between reading the newspaper and a fundamental knowledge of contemporary professional, societal, and global issues may not be intuitively obvious to the casual student. With over $83 \%$ at least agreeing with the last statement, students strongly endorsed the utility of classroom 
instruction for raising the awareness of the expectations by industry for ethical behavior by practicing engineers.

\section{f. A Commitment to Quality, Timeliness, and Continuous Improvement (ABET Criteria k)}

Naturally, the $2^{\text {nd }}$ student presentation dealing directly with quality control and continuous improvement in the industry (See Section "a" above) provided a timely target of opportunity for the students to recognize the utility and serious nature of this issue. In engineering, there may not be a more critical fundamental to the survival of a corporation dedicated to providing products and services to a public with a long memory. However, the policies of the course also reinforced the concept of continuous improvement by providing iterative opportunities commensurate with meeting course objectives. As discussed earlier with all four writing requirements (See Section "b" above), all written works could be resubmitted after rewrites to improve performance. Implementing constructive feedback and producing an improved product allowed students to personally demonstrate the tenets of continuous improvement. The sequential nature of the two student presentations were also designed to model continuous improvement. Immediately following the first student presentation, groups received both oral and written feedback on their performance in researching, developing, and presenting their group project; consequently, the second student presentation provided an opportunity to iteratively improve.

Assessment results actually target two different measures for this particular area of interest. The first measure concentrated on the second group presentation and measures the percentage of students who achieved an $80 \%$ or better. The target for performance was $80 \%$. Table 6 provides the results for this measure.

Table 6: Assessment results regarding the student's ability to recognize the importance of quality.

\begin{tabular}{|c|c|c|c|c|c|c|}
\hline \multirow{3}{*}{ Target } & \multicolumn{7}{|c|}{ Assessment Results } \\
\cline { 2 - 7 } & $\begin{array}{c}2005 \\
(\text { Fall })\end{array}$ & $\begin{array}{c}2006 \\
(\text { Fall })\end{array}$ & $\begin{array}{c}2007 \\
(\text { Fall })\end{array}$ & $\begin{array}{c}2008 \\
(\text { Fall })\end{array}$ & $\begin{array}{c}2009 \\
(\text { Spring })\end{array}$ & $\begin{array}{c}2009 \\
(\text { Fall) }\end{array}$ \\
\hline $80 \%$ & $95 \%$ & $99 \%$ & $85 \%$ & $100 \%$ & $81 \%$ & $77.3 \%$ \\
\hline
\end{tabular}

Previous recommendations indicated that the $2^{\text {nd }}$ presentation should have a narrower scope focusing primarily on quality and continuous improvement; in previous semesters, it had also included diversity. This semester, diversity split out as a stand-alone topic. The scope of work was also amended to require a comparative analysis of the companies chosen for the presentation. The analytical process required students to develop appropriate criteria, compute weighted averages, and perform a formal evaluation to compare quality programs from different companies. Unfortunately, the technique for comparing alternative quality programs was 
apparently not easily grasped by all the students and the grades actually suffered as a result. Consequently, since the measure is still considered appropriate in application, the curriculum/classroom instruction needs to be modified to include more instruction in this technique.

The second measure for this area of interest measures quite objectively the students' abilities to be timely. More to the point, it measures the percentage of students who submitted more than $85 \%$ of their homework assignments in accordance with the assigned deadlines. The course routinely requires submittals from the students throughout the semester so this measure effectively documents their recognition of the necessity to be timely. The target for this measure was $80 \%$.

Table 7: Assessment results regarding the student's ability to demonstrate a commitment to timeliness.

\begin{tabular}{|c|c|c|c|c|c|c|}
\hline \multirow{2}{*}{ Target } & \multicolumn{7}{|c|}{ Assessment Results } \\
\cline { 2 - 7 } & $\begin{array}{c}2005 \\
(\text { Fall })\end{array}$ & $\begin{array}{c}2006 \\
(\text { Fall })\end{array}$ & $\begin{array}{c}2007 \\
(\text { Fall })\end{array}$ & $\begin{array}{c}2008 \\
(\text { Fall })\end{array}$ & $\begin{array}{c}2009 \\
(\text { Spring })\end{array}$ & $\begin{array}{c}2009 \\
(\text { Fall })\end{array}$ \\
\hline $80 \%$ & $100 \%$ & $96 \%$ & $85 \%$ & $97 \%$ & $100 \%$ & $54.5 \%$ \\
\hline
\end{tabular}

Previous course policies stipulated that absolutely no late work would be accepted; this policy was deemed counterproductive since it precluded the opportunity to assess the students' performance on the required assignment. However, it was effective in motivating students to beat the deadline to avoid the "zero" that would have resulted from being late. This semester, course policies was modified to accept late work on the premise that completing the assignment was the key objective not an arbitrary suspense date. Unfortunately, with no apparent consequence, student commitment to timeliness slipped and performance lagged as Table 7 clearly shows. Nevertheless, perhaps the lack of a clear consequence actually provides a unique opportunity to examine the students' true commitment to timeliness purely for the sake of being punctual, since their motivation must come from them rather than their instructor. Discussion among the faculty has indicated a requirement with no consequence for lateness is not realistic because in the real world, there are almost always penalties for tardiness. Next semester, the mechanism will be modified: $1^{\text {st }}$, a line item on the grade scheme for the course will be developed that tracks and assesses the students' ability to meet a suspense and submit work in a timely manner. However, the policy of accepting late work will also continue with students being apprised that although late work is accepted, tardy submittals will directly impact their course grade through the "timeliness" grade line.

Student end-of-semester feedback solicited input on the effectiveness of the cultural events, the current events quizzes, and associated classroom discussions. Specifically, students responded to the following questions: 
f1. "The group project allowed me to research quality and continuous improvement in my industry and contributed to a personal recognition and commitment to quality and continuous improvement."

f2. "The ability to resubmit written submissions afforded me the opportunity to practice and to directly benefit from a policy based on continuous improvement."

f3. "The second presentation where I implemented constructive feedback from the first oral presentation allowed me to practice and to directly benefit from a policy based on continuous improvement."

Figure 6 shows a relatively strong response by the students in this area. On the first question, $78 \%$ at least agreed indicating perhaps that they had understood the commitment of industry to quality and had internalized it on a personal level. The second and third responses testify to a recognition of the significance of classroom policies and procedures as a model for continuous improvement. $65 \%$ of the students agreed that they directly benefited from the rewrite-resubmit policy, and $72 \%$ agreed similarly that their $2^{\text {nd }}$ group project and presentation also benefitted. Recognizing the tangible benefits from this policy was considered a distinct success by the faculty.

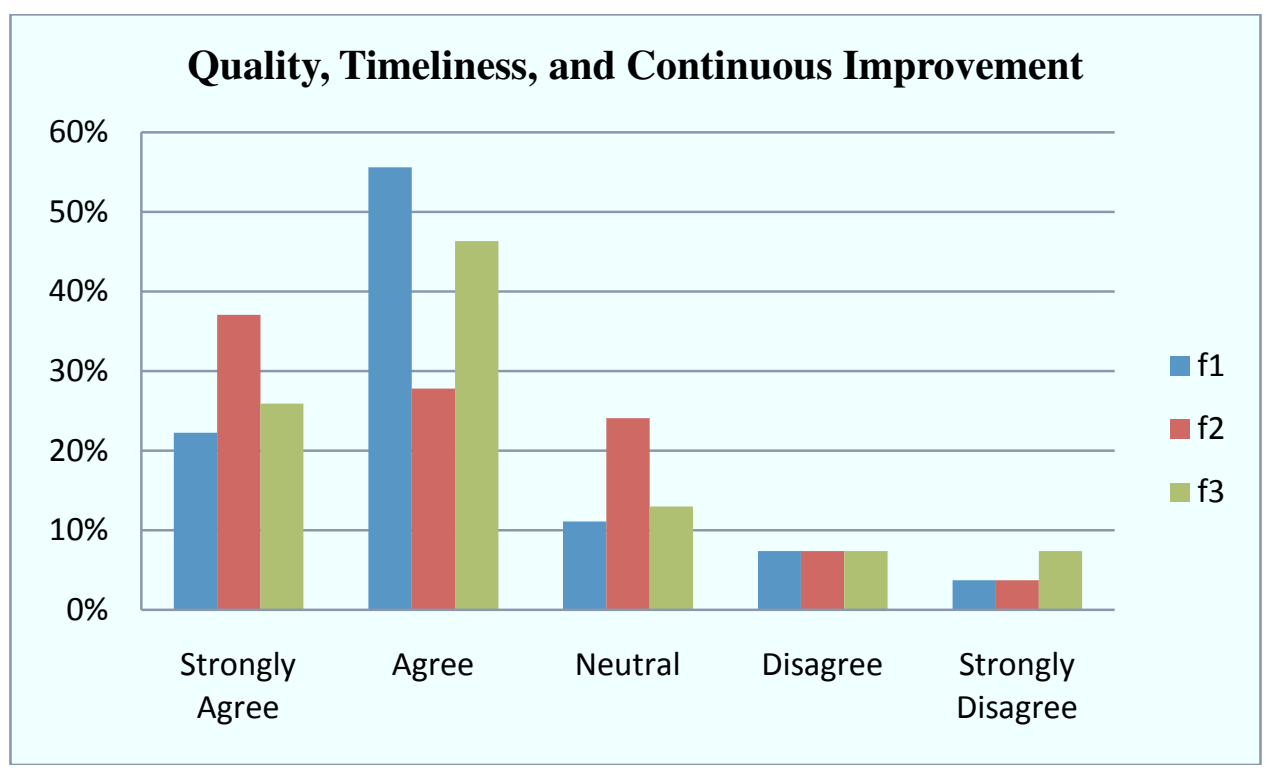

Figure 6: Student response to questions $\mathrm{f} 1, \mathrm{f} 2$, and $\mathrm{f} 3$ noted above.

(Note: $\mathrm{N}=54$ student responses.) 


\section{Conclusion}

This paper describes practical techniques currently employed to effectively integrate ABET accreditation criteria for engineering technology (TC2K) into a junior-level seminar course. As presented, it is apparent that this is an integrated approach that recognizes the inter-relationship not only among the criteria but also among the policies, procedures, and events included within the confines of the course itself. This diverse, multi-disciplined course provides a unique target of opportunity for significantly impacting these future engineers in these "soft" engineering skill sets. Evolved over the past five years, this "non-technical" course employs a number of innovative techniques to explore a wide range of relevant topics pertinent to their success as a student and as a future practicing engineer. These techniques for instructing, assessing, and evaluating the ABET criteria presented here are truly exportable and can be implemented directly in other similar programs and courses. This is a success story for this University and Department, but it is also a template for promoting excellence both in other academic institutions and in industry professional development programs.

Bibliography

1. 2010-2011 Criteria for Accrediting Engineering Technology Programs, ABET, Baltimore, Maryland, 2009 


\section{APPENDIX A: PEER EVALUATION WORKSHEET \& ANALYSIS}

Each member of the group would receive and complete a blank form similar to Figure A-1 below, evaluating each of the other members in their relative contribution to finished project. Peer evaluations are considered confidential and must be confined to a range of $0.85-1.15$. The evaluation system requires that the ratings balance and numerically equal the total number being evaluated. Consequently, in the example, Tom failed to carry his weight (hence the core of 0.90 ) so logically someone else had to step up; in Johnny's assessment, Tony and Betty equally worked to make up his shortcomings (equal scores of 1.05). Note that the final ratings sum up appropriately or $0.90+1.05+1.05=3.00$. Table A-1 demonstrates the impact of the scores on the final grade. The average score for each member is multiplied by the raw group grade for the project resulting in individualized grades for each respective member tempered by the collective peer evaluation.

\begin{tabular}{|c|c|c|c|}
\hline \multirow[t]{4}{*}{ Group \#: 18} & \multicolumn{3}{|c|}{ Group Members: \#1. _ Johnny Debb } \\
\hline & & & Tom Jones \\
\hline & & & Tony Romo \\
\hline & & & Betty Crocker \\
\hline Name & $\begin{array}{c}\text { Score } \\
(\text { Range }= \\
0.85-1.15)\end{array}$ & & Comments \\
\hline Tom Jones & 0.90 & $\begin{array}{l}\text { Missed some cr } \\
\text { write up or the }\end{array}$ & $\begin{array}{l}\text { ritical meetings and did not contribute to the } \\
\text { oral presentation. }\end{array}$ \\
\hline Tony Romo & 1.05 & $\begin{array}{l}\text { Really did a lot } \\
\text { document. }\end{array}$ & during the project, particularly with the final \\
\hline Betty Crocker & 1.05 & Overall good pa & articipator. \\
\hline Total & 3.00 & $\begin{array}{l}\text { Note: "Total" } m \\
\text { 3.0 }\end{array}$ & ust equal the number of rated team members or \\
\hline
\end{tabular}

Figure A-1: Completed sample peer evaluation by "Johnny Debb" on his fellow group members.

Table A-1: Example of Total Group Assessments and Resulting Final Grades:

\begin{tabular}{|c|c|c|c|c|c|c|c|c|}
\hline \multirow{2}{*}{$\begin{array}{c}\text { Team } \\
18\end{array}$} & \multirow{2}{*}{$\begin{array}{c}\text { Johnny } \\
\text { Debb }\end{array}$} & \multirow{2}{*}{$\begin{array}{c}\text { Tom } \\
\text { Jones }\end{array}$} & \multirow{2}{*}{$\begin{array}{l}\text { Tony } \\
\text { Romo }\end{array}$} & \multirow{2}{*}{$\begin{array}{c}\text { Betty } \\
\text { Crocker }\end{array}$} & \multicolumn{2}{|c|}{ Peer Rating Results } & \multirow{2}{*}{$\begin{array}{c}\text { Raw } \\
\text { Group } \\
\text { Score } \\
\end{array}$} & \multirow{2}{*}{$\begin{array}{r}\text { Final } \\
\text { Grade }\end{array}$} \\
\hline & & & & & Total & Average & & \\
\hline $\begin{array}{c}\text { Johnny } \\
\text { Debb }\end{array}$ & & 1.15 & 0.95 & 1.05 & 3.15 & 1.050 & \multirow{4}{*}{$\begin{array}{c}90 \% \\
\text { A- }\end{array}$} & $\begin{array}{c}94.5 \% \\
\text { A }\end{array}$ \\
\hline $\begin{array}{l}\text { Tom } \\
\text { Jones }\end{array}$ & 0.90 & & 1 & 1 & 2.90 & 0.966 & & $\begin{array}{c}87.0 \% \\
\text { B }+\end{array}$ \\
\hline $\begin{array}{l}\text { Tony } \\
\text { Romo }\end{array}$ & 1.05 & 0.95 & & .95 & 2.95 & 0.983 & & $\begin{array}{c}\mathbf{8 8 . 5 \%} \\
\mathrm{B}+\end{array}$ \\
\hline $\begin{array}{c}\text { Betty } \\
\text { Crocker }\end{array}$ & 1.05 & 0.90 & 1.05 & & 3.00 & 1.000 & & $\begin{array}{c}90.0 \% \\
\text { A- }\end{array}$ \\
\hline Totals & 3.00 & 3.00 & 3.00 & 3.00 & Samp & Math: & $0 \times 90^{\circ}$ & $=94.5 \%$ \\
\hline
\end{tabular}


Cultural Etiquette 101 (Student Workshop)

We all will have a cultural "slip up", but there are some things that we can do to avoid them. Learn a few ground rules regarding language, space, time, \& more as well as learn some tips to help survive those disaster moments.

Wednesday, September 9 Student Union (STUN) 200

Tuesday, September $15 \quad$ STUN 200

$$
\begin{array}{r}
12: 00 \text { noon }-1: 00 \mathrm{pm} \\
2: 00 \mathrm{pm}-3: 00 \mathrm{pm}
\end{array}
$$

Scientology 101: Exploring the Foundational Beliefs of the Church of Scientology

Join Mr. Carl Rubidge and fellow Scientology practitioners in a presentation of the history and fundamental beliefs of the Church of Scientology

Wednesday, September 16 STUN 200

Sponsored by Religious \& Spiritual Life (a sub-unit of the Multicultural Resource Center)

Becoming Unstoppable: How to Move Forward When You Feel Like Quitting featuring Andres

"The Cuban Guy" Lara

Mr. Lara left Cuba at the age of 16 and arrived in the United States...without his parents...without any money...without a home...and without knowing a word of English. His amazing experience has led him to become an author, entrepreneur, and motivational speaker. Monday, September 28 STUN Multipurpose Room (GHI) 7:00pm

Hip Hop: Beyond Beats \& Rhymes (film/dialogue)

This documentary explores the representations of gender roles in hip hop and rap music through the lens of filmmaker Byron Hurt, a former college athlete turned activist. A discussion immediately follows the viewing.

Wednesday, September 30 STUN Theatre (163)

7:00pm

Seasons of Diversity (Student workshop)

For a number of us, exploring diversity is a new experience. It can be a challenge even to those that feel that they are "seasoned". This workshop will explore how our "seasons" affect our views of and experiences with diversity.

Tuesday, October $6 \quad$ STUN 200

Wednesday, October 28 STUN

2:00pm - 3:00pm

12 noon $-1: 00 \mathrm{pm}$

"OUTSpoken" presents Keith Boykin: Keith Boykin is the editor of The Daily Voice online news site, a CNBC contributor, a BET TV host and a New York Times best-selling author of three books. Educated at Dartmouth and Harvard, Keith attended law school with President Barack Obama and served in the White House as a special assistant to President Bill Clinton. Boykin's most recent book, Beyond the Down Low: Sex, Lies and Denial in Black America focusing on the down-low phenomenon, was published in February 2005 and released in paperback in February 2006. From December 2003 until April 2006, Boykin served as president of the board of the National Black Justice Coalition, a Washington-based civil rights organization dedicated to fighting racism and homophobia. 
This speaker is presented with assistance from the Chancellor's Diversity Challenge Fund, the Wesley Mancini Foundation, the Black Student Union, the Center for Professional \& Applied Ethics, Women's \& Gender Studies, Counseling Center, Multicultural Resource Center, and PRIDE.

Wednesday, October 7 McKnight Hall (Cone Univ. Center) 7:00pm

Luca "Lazy Legs" Patuelli

Learn the story of a young man born with arthrogryposis (muscle disorder that limits motion in the joints), who, years later, was diagnosed with sciolosis (a condition that affects the curve of the spine), and who went on to become an international, award-winning break dancer.

Tuesday, October $20 \quad$ Student Union Theatre (163)

7:00pm

\section{Let Your Children Tell}

This theatre documentary explores the Holocaust and follows the lives of young people from Austria, Hungary, and The Netherlands through their diary entries. The four-person production explores racism, religious oppression, and other forms of discrimination. Monday, October $26 \quad$ McKnight Hall 7:00pm Sponsored by Religious \& Spiritual Life with the assistance of the Touring Theatre of North Carolina.

You May (Not) Be Smarter Than You Think (Student Workshop) Interacting with different individuals requires us to "shift perspectives", which isn't an easy thing to do. Many times, we engage with others in ways that are comfortable for us, but not for them. This workshop will explore our emotional and cultural intelligence and how this affects our various interactions.

Wednesday, November 4 STUN 200

Tuesday, November $10 \quad$ STUN 200

12noon - 1:00pm

2:00pm - 3:00pm

Poverty Simulation

Friday, November $6 \quad$ Lucas Room (Cone Univ. Center) Session 1: 10:00am - 12:00pm

Session 2: 1:00pm - 3:00pm

(There are two separate sessions offered to accommodate the growing interest in this activity. Individual participants must RSVP with the Multicultural Resource Center by Tuesday, November 3.)

What Do Quakers Believe?

Join in a presentation exploring the beliefs and practices of the Religious Society of Friends (Quakers). This workshop is provided in conjunction with Charlotte's Mecklenburg Ministries. Wednesday, November 11 STUN 200 Sponsored by Religious \& Spiritual Life

6:30pm

The Native American Dream

Come enjoy storytelling and activities as we celebrate Native American Heritage Month. Enjoy tribal stories, and take advantage of the opportunity to create your own Dream Catcher or God's Eye.

Monday, November 16

Norm's (Student Union)

*Co-sponsored by the Campus Activity Board (CAB) 